\title{
ПЕДАГОГІЧНІ ТЕХНОЛОГІЇ ФОРМУВАННЯ ІНШОМОВНОЇ КОМУНІКАТИВНОЇ КОМПЕТЕНТНОСТІ ДЛЯ МІЖКУЛЬТУРНОГО СПІЛКУВАННЯ В ПОЧАТКОВІЙ ШКОЛІ НУШ
}

Анотація. У статті розглядаються педагогічні технології формування іншомовної комунікативної компетентності для міжкультурного спілкування в початковій школі НУШ; обгрунтовуються фрактори та умови, що впливають на формування іншомовної комунікативної компетентності здобувачів освіти. Концепщія іншомовної комунікативної компетентності передбачає формування навичок та вмінь, які дозволяють долучитися до етнокультурних цінностей країни мови, що вивчається, і практично користуватися іноземною мовою в ситуащіях міжкультурного взаєморозуміння і пізнання. Розкривається зміст таких понять як «міжкультурне спілкування», «педагогічна технологія», «ігрові технології навчання», "технологія проектного навчання». Наводяться приклади традиційних та інноваційних педагогічних технологій фрормування даної компетентності. Акцент робиться на соціокультурному аспекті, як важливому складнику формування міжкультурного спілкування.

Ключові слова: міжкультурне спілкування, педагогічна технологія, методика викладання англійської мови.

Yarema Olena

Brody Markiian Shashkevych Professional Pedagogical College

\section{PEDAGOGICAL TECHNOLOGIES OF FOREIGN LANGUAGE COMMUNICATIVE COMPETENCE FORMATION FOR INTERCULTURAL COMMUNICATION IN PRIMARY SCHOOL OF NUS}

Summary. The article considers pedagogical technologies of formation of foreign language communicative competence for intercultural communication in NUS primary school; the factors and conditions influencing the formation of foreign language communicative competence of students are substantiated. The concept of foreign language communicative competence involves the formation of skills and abilities that allow to join the ethnocultural values of the country of the language being studied, and practically use a foreign language in situations of intercultural understanding and cognition. The content of such concepts as "intercultural communication", "pedagogical technology", "game learning technologies", "project learning technology" is revealed. Examples of traditional and innovative pedagogical technologies of formation of foreign language communicative competence for intercultural communication in primary school of NUS are given. The most effective technologies of intercultural communication development are described, such as: game learning technologies and project training used at foreign language lessons at the primary stage of NUS. Due to the fact that the high level of foreign language communicative competence allows students quickly adapt to life in modern society, which encourages cooperation with different cultures, it is necessary to begin its formation at the initial stage of learning a foreign language. Application in foreign language lessons in primary school games and project-based learning technologies, in our opinion, are the most effective in the development of intercultural communication, as game learning technologies provide a high degree of cognitive independence. Project-based learning technology gives younger students the opportunity to demonstrate creative abilities to learn to express their opinion, argue it, and listen to other people's opinions.

Keywords: intercultural communication, pedagogical technology, English language teaching methodology.

Постановка проблеми. В сучасній світовій спільноті проходять значущі зміни, пов'язані з процесами глобалізації та інтеграції, які ставлять вимогу спілкуватися 3 представниками інших культур. Співпраця України 3 країнами Свросоюзу, розширення політичних, соціальних та економічних відносин нашої країни спонукають до розвитку взаємодії з іншими країнами і народами. Ці взаємодії, в свою чергу, вимагають високого рівня розвитку іншомовної комунікативної компетентності для міжкультурного спілкування, основа якого закладається вже на початковому етапі навчання іноземної мови. Державний стандарт початкової освіти визначає, що «метою іншомовної освіти є формування іншомовної комунікативної компетентності для безпосереднього та опосередкованого міжкуль- турного спілкування, що забезпечуе розвиток інших ключових компетентностей та задоволення різних життевих потреб здобувача освіти. Здобувач освіти - сприймає інформацію, висловлену іноземною мовою в умовах безпосереднього та опосередкованого міжкультурного спілкування, та критично оцінюе таку інформацію» [2].

Міжкультурне спілкування необхідне в світі, де відносини між людьми різних народів стали вільними. Воно веде до розуміння та гармонії. Здатність сприймати і розуміти оточуючих людей і їхні погляди - великий крок на шляху до створення розвинених цивілізацій 3 великим потенціалом. Необхідно навчити дітей розуміти і сприймати культурні схожі та відмінні риси, вчитися пристосовуватися до іншого способу життя починаючи з перших років навчання в школі, 
у віці, який є найбільш оптимальним для ознайомлення 3 іншими культурами.

Аналіз останніх досліджень і публікацій. Проблему розвитку іншомовної комунікативної компетентності розглядали такі дослідники, як: І. Зимня, Л. Буркун, О. Вишневський, Ю. Пассов, Г. Китайгородська та ін. Дослідники зробили великий внесок в теорію й практику навчання іноземної мови. Заслуговують уваги думки науковців щодо необхідності вивчення іноземної мови через вивчення елементів культури, про що нам говорять наукові праці О. Тернопільської, Ю. Пасова, П. Сисоєва, В. Сластьоніна та ін. Зарубіжні вчені М. Мескон і Д. Робінсон вважають, що неефрективне спілкування часто є однією з суттевих перешкод на шляху досягнення успіху.

На думку А. В. Соболевої і О. А. Обдалової, міжкультурне спілкування - це «інтегративна якість особистості, яка характеризується сукупністю комунікативних і когнітивних ресурсів, що виражена у певних знаннях, уміннях і здібностях, які дозволяють їй бути ефективним учасником міжкультурного спілкування, яке формуеться в особливих психолого-педагогічних умовах, що створюють викладачі в процесі навчання» [4, с. 148-149].

Виділення не вирішених раніше частин загальної проблеми. Актуальним на даний час залишається визначення найбільш дієвих педагогічних технологій формування іншомовної комунікативної компетентності для міжкультурного спілкування в початковій школі НУШ.

Мета статті. Головною метою цієї роботи $є$ огляд та аналіз основних педагогічних технологій формування іншомовної комунікативної компетентності для міжкультурного спілкування в початковій школі НУШ.

Виклад основного матеріалу. Для формування іншомовної комунікативної компетентності для міжкультурного спілкування в початковій школі НУШ можна використовувати різні педагогічні технології, наприклад: технологію проблемного навчання (Джон Дьюі); технологію комунікативного навчання іншомовної культури (Є.I. Пассов); технологію програмованого навчання (Б. Скіннер, В.П. Беспалько); технологію «Діалог культур» (В.С. Біблер, С.Ю. Курганов); технологію розвиваючого навчання (Л.С. Виготський, Л.В. Занков); технологію проєктного навчання (Дж. Дьюі, В. Кілпатрик); технологію диференційованого навчання дітей за інтересами (І.Н. Закатова); технологію ігрового навчання (Б.П. Нікітін) та інші [1].

Розглянемо перш за все термін «педагогічна технологія». Педагогічна технологія - один iз спеціальних напрямків педагогічної науки (прикладна педагогіка), покликаний забезпечити досягнення певних завдань, підвищувати ефективність навчально-виховного рівня, гарантувати його високий рівень. Отже, організація різних видів педагогічної діяльності передбачає використання варіативних технологій на рівні творчості та майстерності. У сучасній дидактиці представлені найрізноманітніші технології, бо кожен автор і виконавець приносять в педагогічний процес щось своє індивідуальне.

М. Кларк вважає, що сенс педагогічної технології полягає в застосуванні в сфері освіти вина- ходів, промислових виробів та процесів, які є частиною технології нашої часу. Сучасний словник термінів ЮНЕСКО пропонуе таке визначення: педагогічні технології це систематичний метод планування, застосування і оцінювання всього процесу навчання та засвоєння знань шляхом обліку людських та технічних ресурсів та взаємодії між ними для досягнення більш ефрективної форми освіти. П.Д. Мітчелл в результаті аналізу більше ста джерел пов'язаних з визначенням терміну, вважає, що педагогічна технологія це область дослідження та практики (у рамках системи освіти), має зв'язок з усіма аспектами організації педагогічних систем i процедурою розподілу ресурсів для досягнення специфічних i потенційно відтворюваних результатів. М.В. Кларін розглядає «педагогічну технологію, як системну сукупність і порядок фрункціонування всіх особистісних, інструментальних та методичних засобів, що використовуються для досягнення педагогічних цілей» [1, с. 29].

Спираючись на наведені вище визначення, ми можемо зробити висновок, що всі педагогічні технології мають: логічно обгрунтовану систему етапів і цілей навчання; характеристику способів взаємодії та діяльності учасників освітнього процесу; можливість трансформації умови; наявність системи діагностики, яка забезпечуе досягнення поставлених цілей.

Розглянувши різноманітні педагогічні технології формування іншомовної комунікативної компетентності для міжкультурного спілкування в початковій школі НУШ, ми визначили, що на уроках іноземної мови для розвитку міжкультурної компетенції найбільш ефрективним буде використання таких технологій, як технології ігрового та технології проектного навчання.

На думку багатьох науковців саме технологія ігрового навчання $є$ найедективнішою для практики міжкультурного спілкування.

Прийнято виділяти деякі форми ігрової діяльності, які можна застосовувати на уроках іноземної мови в початковій школі: імітаційні ігри, під час яких учасники можуть оцінити свою здатність до роботи в команді, виявити навички критичного мислення, лідерські та ділові якості; рольові ігри, де учасники навчального процесу мають змогу проявити себе в ролі іншої особистості, розкриваючи позитивні або негативні якості персонажів; ділові ігри, під час яких здобувачі освіти отримують можливість навчитися займати активну життеву позищію, визначитися 3 вибором майбутнього профресії. Дослідники виділяють також таку форму ігрової діяльності, як біографічну рефлексію, під якою розуміють осмислення власної біографрї з метою з'ясування основ своєї власної ідентичності та подальше порівняння свого життя 3 життям однолітків за кордоном [3].

Наведемо приклад використання гри «Привіт! Я - Ваш гід!» на уроці іноземної мови в початковій школі НУШ. Мета гри полягає в тому, щоб оживити в пам'яті раніше засвоєнні знання учнів про культуру країни мови, що вивчається, і сприяти розвитку швидкості реакції та мислення учнів.

Гра «Привіт! Я - Ваш гід!» полягає в тому, що спочатку клас обирає лідера, що виконує роль, 
власне, гіда, та групу здобувачів освіти, які виконують роль туристів. Кожен із групи «туристів» запитуе лідера про країну, їі географічне положення, столицю, традиції, права і обов'язки громадян. Якщо лідер не знає відповіді на питання, «група туристів» обирає іншого "гіда», серед здобувачів освіти, що не приймали до цього моменту участі.

Технологія проєктного навчання $є$ едекктивною при розвитку міжкультурної компетенції під час уроків іноземної мови в НУШ, так як ії мета полягає в можливості продемонструвати творчі здібності здобувачів освіти, використовуючи при цьму набуті знання у лексиці, граматиці, здатності висловлювати свою думку, аргументувати iii, а також прислухатися до думки інших людей.

Проєкт виступає дидактичним засобом навчання, який дозволяе розвивати вміння проєктування. Проєкт на уроках англійської мови на початковій ланщі в НУШ дає здобувачам освіти досвід пошуку інформащії, практичного застосування самонавчання, саморозвитку, самореалізації та самоаналізу своєї діяльності. Проєктна діяльність молодших школярів, як основна структурна одиниця процесу навчання, сприяе розвитку загальних навичок. Проєкт може бути представлений як малюнок, плакат, концерт, спектакль, гра, вікторина, інтерв'ю тощо.

Наведемо приклад використання проекту «Майстер шефф» (створюеться після вивчення лексики на тему «Іжа») на уроці англійської мови в початковій школі НУШ. На першому етапі роботи над проєктом вчителю необхідно створити проблемну ситуацію, наприклад, запропонувати здобувачам освіти уявити себе учасниками програми «Майстер шеф». Учасникам навчального процесу необхідно скласти список продуктів, створити рецепт страви, 3 цих продуктів, та продемонструвати готовий результат високоповажному журі, тобто вчителю. Дозволяється працювати 3 різними адаптованими для дітей молодшого шкільного віку джерелами інфор- мащії (інтернет, журнали, телепрограми тощо). Далі молодші школярі оформлюють свої результати у вигляді плакатів або мультимедійних презентацій. Коли робота над проєктом вважається закінченою, її захищають, після чого порівнюють отримані результати, роблять висновки та проводять взаємну оцінку робіт.

Висновки і пропозиції. Підводячи риску, можна відзначити, що іншомовна комунікативна компетентність для міжкультурного спілкування в початковій школі НУШ розуміється, як сукупність знань, умінь та здібностей, які забезпечать успішну взаємодію між представниками різних культур та здобувачами освіти.

Доведено, що здобувачі освіти, оволодівши високим рівнем міжкультурною іншомовною компетентністю, швидше пристосовуються до життя в сучасному світі, легко знаходять контакт 3 представниками інших культур і національностей. Але починати формувати іншомовну комунікативну міжкультурну компетентність потрібно в початковій ланщі НУШ.

Найбільш ефрективними для фрормування іншомовної комунікативної компетентності для міжкультурного спілкування в початковій школі НУШ є ігрові і проєктні технології навчання. Технології ігрового навчання забезпечують високий ступінь прояву пізнавальної самостійності здобувачів освіти, а також дозволяють їм перейти 3 позиції об'єкта навчання на позицію суб'єкта діяльності та спілкування. Проявити свої творчі здібності, використовуючи знання і досвід, здобутий під час уроків, навчитися висловлювати свою думку, аргументувати їі, а також чути думку інших і поважати її дозволяе технологія проєктного навчання. Перспективи подальших наукових пошуків бачимо у детальному вивченні особливостей застосування різноманітних педагогічних технологій формування іншомовної комунікативної компетентності для міжкультурного спілкування в початковій школі НУШ.

\section{Список літератури:}

1. Беспалько В. П. Педагогика и прогрессивные технологии обучения. Москва, 1995. 342 с.

2. Державний стандарт початкової освіти. URL: https://zakon.rada.gov.ua/laws/show/688-2019-\%D0\%BF\#Text

3. Шаповал I.C. Ігрові технології як інструмент компетентнісно оріентованого навчання на уроці англійської мови. URL: https://naurok.com.ua/stattya-igrovi-tehnologi-yak-instrument-kompetentnisno-orientovanogonavchannya-na-uroci-angliysko-movi-243533.html

4. Соболева А. В., Обдалова О. А. Когнітивна готовність до міжкультурного спілкування як необхідний компонент міжкультурної компетенції. Мова та культура. 2015. № 1(29). С. 146-155.

\section{References:}

1. Bespal'ko V.P. (1995) Pedagogika i progressivnye tehnologii obuchenija. Moscow. (in Russian)

2. Derzhavnyi standart pochatkovoi osvity [State Standart of Primary Education]. Available at: https://zakon.rada.gov.ua/ laws/show/688-2019-\%D0\%BF\#Text

3. Shapoval I. S. Igrovi texnologiyi yak instrument kompetentnisno oriyentovanogo navchannya na uroci anglijskoyi movy. Na Urok. Available at: https://naurok.com.ua/stattya-igrovi-tehnologi-yak-instrument-kompetentnisnoorientovanogo-navchannya-na-uroci-angliysko-movi-243533.html

4. Sobolyeva A.V., Obdalova O.A. (2015) Kognityvna gotovnist do mizhkulturnogo spilkuvannya yak neobxidnyj komponent mizhkulturnoyi kompetenciyi. Mova ta kultura, vol. 1, no. 29, pp. 146-155. 